
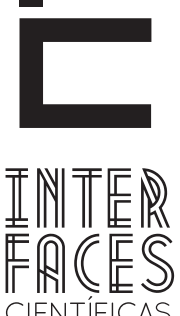

CIENTÍFICAS

HUMANASE SOCIAIS

ISSN IMPRESSO 2316-3348

E-ISSN 2316-3801

DOI - 10.17564/2316-3801.2018v7n2p77-90

\title{
SOMBRAS DA MEMÓRIA: HISTÓRIAS DE VIOLAÇ̃̃ES DOS DIREITOS HUMANOS DURANTE AS DITADURAS CIVIS-MILLTARES NO CONE SUL
}

MEMORY SHADOWS: HISTORIES OF HUMAN RIGHTS VIOLATIONS DURING THE CIVIL-MILTTARY DICTATORS IN THE SOUTHERN CONE

SOMBRAS DE LA MEMORIA: HISTORIAS DE VIOLACIÓN DE LOS DERECHOS HUMANOS DURANTE LAS DITADURAS CIVIL-MILTARES EN EL CONO SUR

Anna Flávia Arruda Lanna Barreto ${ }^{1}$

\section{RESUMO}

O objetivo deste artigo é relatar memórias sobre violações dos direitos humanos de mulheres e crianças durante as ditaduras civis e militares no Cone Sul, registradas noFundo Clamor, localizado no Centro de Documentação e Informação Científica (CEDIC), da Pontifícia Universidade Católica de São Paulo e nos Arquivos do Terror, localizado noCentro de Documentação e Arquivo para a Defesa dos Direitos Humanos (CDyA) da Corte Suprema de Justiça do Paraguai, que contém registros dos trinta e cinco anos da ditadura militar de Alfredo Stroessner no Paraguai.A metodologia adotada para a realização desta pesquisa, de ordem descritiva qualitativa, é baseada na análise documental e bibliográfica, tomando como referência fontes históricas de origens militar e civil, bem como depoimentos e registros escritos (dossiês, documentos jurídicos, denúncias, cartas, reportagens, boletins, folhetos e relatórios). A partir da realização dessa pesquisa, concluímos que os registros do Comitê em Defesa dos Direitos Humanos dos Refugiados dos Países do Cone Sul, disponíveis no Fundo Clamor e os registros dos Arquivos do Terror têm contribuído, de forma significativa, para o resgate da memória his- 
tórica do período ditatorial e para a conquista da cidadania plena nesses países, sendo o Brasil protagonista da implantação da Doutrina de Segurança Nacional na América do Sul.

\section{ABSTRACT}

The purpose of this article is to report on the human rights violations of women and children during the civil and military dictatorships in the Southern Cone, registered in the Clamor Fund, located at the Center for Documentation and Scientific Information (CE$D / C)$, Pontifical Catholic University of São Paulo, and in the Archives of Terror, located in the Center for Documentation and Archives for the Defense of Human Rights (CDyA) of the Supreme Court of Justice of Paraguay, which contains records of the thirty-five years of the military dictatorship of Alfredo Stroessner in Paraguay. The methodology used to conduct this qualitative descriptive research is based on documental and bibliographic analysis, taking as reference historical sources of military and civil origins, as well as testimonies and written records (dossiers, legal docu-

\section{PALAVRAS-CHAVE}

Ditadura Cone Sul. Direitos Humanos. Terror. Memória. História.

ments, denunciations, letters, reports, bulletins, leaflets and reports). Based on this research, we conclude that the records of the Committee on Human Rights of Refugees of the Southern Cone Countries available in the Clamor Fund and the records of the Archives of Terror have contributed significantly to the rescue of memory historical period of the dictatorial period and for the conquest of the full citizenship in these countries, being Brazil protagonist of the implantation of the Doctrine of National Security in South America.

\section{KEYWORDS}

Southern Cone Dictatorship. Human Rights. Horror. Memory. History.

\section{RESUMEN}

El objetivo de este artículo es relatar memorias sobre violaciones de losderechos humanos de mujeres y niños durante lasdictadurasciviles y militares enelConoSur, registradas enelFondo Clamor, ubicadoenel Centro de Documentación e Información Científica (CEDIC), de laPontificiaUniversidad Católica de São Paulo, y enlosArchivosdel Terror, ubicadoenel Centro de Documentación y Archivo para la Defensa de losDerechos Humanos (CDyA) de la Corte Suprema de JusticiadelParaguay, que contiene registros de lostreinta y cinco años de ladictadura militar de Alfredo Stroessner enParaguay. La metodología adoptada

para larealización de esta investigación, de ordendescriptivocualitativo, se basaenelanálisis documental y bibliográfico, tomando como referenciafuentes históricas de orígenes militar y civil, así como testimonios y registros escritos (dosieres, documentos jurídicos, denuncias, cartas, reportajes, boletines, folletos e informes). A partir de larealización de esta investigación, concluimos que los registros del Comité en Defensa de losDerechos Humanos de los Refugiados de los Países delConoSur, disponiblesenelFondo Clamor, y los registros de losArchivosdel Terror hancontribuido, de forma significativa, al rescate de lamemoria histórica 
del período dictatorial y para la conquista de laciudadanía plena enesos países, siendoel Brasil protagonista de laimplantación de laDoctrina de Seguridad Nacional en América delSur.

\section{INTRODUÇÃO}

ARTIGO 1. Os homens nascem e permanecem livres e iguais em direitos. As distinções sociais não podem ser fundamentadas senão sobre a utilidade comum. ARTIGO 2. A finalidade de toda associação política é a conservação dos direitos naturais e imprescritíveis do homem. Esses direitos são: a liberdade, a prosperidade, a segurança e a resistência à opressão.

ARTIGO 3. Princípio de toda soberania reside essencialmente na nação; nenhum corpo, nenhum indivíduo pode exercer autoridade que dela não emane expressamente... (Declaração dos Direitos do Homem e do Cidadão, 26 de agosto de 1789).

Paradoxalmente, passados mais de dois séculos, a promessa de universalidade dos Direitos Humanos ainda encontra obstáculos para a sua efetivação. Após anos de desrespeito sumário aos direitos humanos dos povos sul-americanos, sobretudo nos períodos das ditaduras civis e militares, que contaram com a prática hedionda da tortura, do desaparecimento forçado, sequestro e ocultação de identidades de milhares de militantes políticos contrários aos regimes instalados, vários cidadãos e familiares de desaparecidos políticos ainda aguardam a efetiva igualdade de direitos à memória, ao conhecimento dos fatos, a identificação dos entes queridos.

Nossa atenção se volta para os casos de crianças desaparecidas, sequestradas, apropriadas, presas e torturadas, filhas de militantes políticos e opositores das ditaduras do Cone Sul e do Brasil, registrados no Fundo do Comitê de Defesa dos Direitos Humanos para os Países do Cone Sul (Clamor), do Centro de Documentação e Informação Científica (CEDIC), Pontifícia Universidade Católica de São Paulo / SP, entre os anos de 1970-1990² e nos Arquivos do Terror, do Centro de Documentación y Archivo para la Defensa

\section{PALABRAS CLAVE}

DictaduraConoSur. Derechos Humanos. Terror. La memoria. Historia.

de los Derechos Humanos- CDyA da Corte Suprema de Justiça do Paraguai.

O objetivo desta pesquisa é analisar o conteúdo documental do Fundo Clamor (1970-1990) e dos "Arquivos do Terror" (1954-1989)³, e sua contribuição para o processo de resgate da memória histórica dos casos de sequestro, prisões e tortura de crianças, fiIhas de militantes políticos, durante as ditaduras civis e militares no Cone Sul.

A metodologia adotada baseia-se na análise crítica dos registros documentais encontrados nos arquivos do Fundo Clamor (fichas, dossiês, correspondências, testemunhos e denúncias escritas), comparando-os com os registros encontrados nos Arquivos do Terror, cuja origem remonta aos órgãos de segurança nacional dos países do Cone Sul.

Há um consenso na historiografia sobre o protagonismo do Brasil em ações de apoio e sustentação das ditaduras que se instalaram no Cone Sul após 1964. Este protagonismo incluía ações de repressão, sobretudo troca de informações, fornecimento de documentos, troca de prisioneiros, treinamento em área de inteligência e em técnicas de "interrogatório" com a colaboração dos serviços secretos norte-americanos e britânicos.

A historiografia analisa que esse processo se expandiu e intensificou ao longo de quase vinte anos e identifica pelo menos três estágios distintos de colaboração entre as ditaduras, com participação brasileira. 0 primeiro estágio começa a partir de 1964 com o golpe militar brasileiro; o segundo, após o início da ditadura chilena em 1973, um estágio que passa a incluir troca de prisioneiros sem registro, sequestros e assassinatos. 0 terceiro estágio, a Condor, a partir de 1975. O Acervo Clamor e os "Arquivos do Terror" são importantes porque eles permitem analisar e perce-

2 Período de documentação dos arquivos do Fundo Clamor.

3 Período de duração da ditadura militar de Alfredo Stroessner. 
ber essas ações e o protagonismo brasileiro nelas.

\section{MEMÓRIAS RESGATADAS, INFÂNCIAS VIOLADAS}

No final dos anos de 1970, quando a ditadura militar brasileira anunciava as primeiras medidas de distensão democrática, os regimes militares do Cone Sul (Argentina, Uruguai, Paraguai e Chile) praticavam medidas de recrudescimento do autoritarismo e de intensificação do aparato repressivo. Prisões arbitrárias, eliminação sumária de militantes políticos, cassações, exílio, banimentos políticos, invasões de domicílios, sequestros e desaparecimento de crianças filhas de militantes políticos ou opositores do regime eram práticas que endossavam a repressão política nos países do Cone Sul e usurpavam os direitos humanos de milhares de brasileiros, chilenos, argentinos, paraguaios e uruguaios.

A ação das forças repressoras desses países procurou, por meio da manipulação dos meios de comunicação e educação, silenciar qualquer manifestação contrária aos interesses econômicos, políticos e ideológicos dos regimes autoritários impostos após a segunda metade do século XX. O sequestro e o desaparecimento de opositores políticos e de seus filhos fizeram parte de um esquema deliberado, que contou com a contribuição conjunta das forças armadas dos países do Cone Sul.

Entre as principais violências cometidas pelos órgãos da repressão, destacam-se assassinatos, torturas, desaparecimentos e sequestros de familiares de militantes políticos, sobretudo, de crianças, filhos de militantes grávidas, presas pela força policial destes países ou por meio da ação conjunta das forças repressoras dos países do Cone Sul, normalmente gerenciada por integrantes da Operação Condor ${ }^{4}$. Segundo relatos e testemunhos registrados no Fundo Clamor e nos Arquivos do Terror, havia listas de adoções para os bebês que nasciam de prisioneiras grávidas detidas

4 Ação conjunta das forças repressoras dos países Brasil, Argentina, Chile, Bolívia, Paraguai, Uruguai, criada em 1975. A função principal dessa operação era neutralizar e reprimir os grupos que se opunham aos regimes militares montados na América do Sul. 0 nome da operação faz referência a uma ave andina, símbolo de astúcia na caça às suas presas. nos cárceres militares. As mulheres eram torturadas e, após o parto, geralmente eram executadas e suas crianças entregues para a adoção, muitas delas para famílias de militares que participaram do assassinato de seus pais biológicos.

Dos ninos, (1) Anatole Boris JulienGrisona, nacido em El Uruguayel 22/09/72, y (2) Eva LucíaJulienGrisona, nacida em la Argentina el 07/05/75, secuestradasel 26/09/76 en Buenos Aires, em una operación conjunta de lasfuerzaspolicialesuruguayas y argentinas, fueron encontradas em laciudad de Valparaíso, Chile. Los ninosestánbien. Sus padres, Roger Julien Cáceres (uruguayo) y Victoria Grisona (argentina), secuestradosenesamismaoperación, continúan desaparecidos. La família enterafuesecuestrada de suresidencia em Partido de San Martín, Provincia de Buenos Aires ${ }^{5}{ }^{6}$

A citação acima se refere a uma denúncia feita pelo Comitê de Defesa dos Direitos Humanos para os Países do Cone Sul (CLAMOR)7, em 1979, a respeito do desaparecimento das crianças uruguaias Anatole Boris JulienGrisona (4 anos) e Eva Lucía Victoria JulienGrisona (1 anos e 4 meses) que foram sequestradas no dia 26 de setembro de 1976, junto com seus pais na Argentina e deportadas ilegalmente para o Chile. Durante a operação de sequestro, os pais dessas crianças foram mortos e seus filhos levados para centros de interrogatórios. Posteriormente foram abandonados numa praça, na cidade de Valparaíso (Chile) e deixados em um orfanato (LIMA, 2003).

A partir de setembro de 1976 os familiares de Ana-

\footnotetext{
5 Boletín de Prensa del 31/07/1979. Fundo Clamor, pasta 1, plástico 60. Arquivo do Comitê de Defesa dos Direitos Humanos para os Países do Cone Sul, do Centro de Documentação e Informação Científica - CEDIC Pontifícia Universidade Católica de São Paulo / SP.

6 "Dois filhos, (1) Anatole Boris JulienGrisona, nascido em Uruguayel 22/09/72, e (2) Eva Lucia JulienGrisona, nascido na Argentina em 07/05/75, seqüestrado em 26/09/76 em Buenos Aires, em uma operação conjunta das forças de polícia uruguaios e argentinos, foram encontradas na cidade de Valparaíso, Chile. As crianças estão bem. Seus pais, Roger Julien Cáceres (uruguaio) e Victoria Grisona (Argentina), seqüestrados na mesma operação, ainda estão desaparecidos. A família inteira foi seqüestrada de sua residência em San Martín partido, província de Buenos Aires."

7 Comitê em Defesa dos Direitos Humanos dos Refugiados dos Países do Cone Sul criado em 1977, apoiado pelo Arcebispo de São Paulo - Cardeal Paulo Evaristo Arns e vinculado à Comissão Arquidiocesana de Pastoral dos Direitos Humanos e Marginalizados. Seu objetivo era prestar proteção e assistência aos refugiados dos países do Cone Sul - Argentina, Brasil, Chile, Paraguai e Uruguai.
} 
tole e Eva Lucía iniciaram uma busca desesperada para reencontrar as crianças. Segundo a historiadora Ananda Simões Fernandes, esta prática se tratava de uma "modalidade de Terrorismo de Estado das ditaduras de Segurança Nacional" (FERNANDES, 2011, p. 48), sobretudo na Argentina, que durante a vigência do regime militar (1976-1983) contou com o alarmante número de 230 crianças sequestradas (BRASIL, 2009).Ações como essas eram utilizadas em técnicas de interrogatório para obtenção de informações consideradas essenciais para o Estado de Segurança Nacional vigente nos países do Cone Sul.

0 avanço de denúncias e pesquisas nessa área apontou para a prática dessa modalidade de "terrorismo de estado" em outros países da América do Sul. No caso argentino, muitas crianças sequestradas tiveram suas identidades omitidas e foram posteriormente adotadas ilegalmente por famílias ligadas direta ou indiretamente à repressão. Exemplo dessa situação é o caso de Mariana Zaffaroni, sequestrada quando tinha dezoito meses de idade, junto com seus pais Jorge Roberto ZaffaronCastilla e MaríaEmilialslas de Zaffaroni em Buenos Aires, no dia 27 de setembro de 1976, por forças da repressão argentina e uruguaia.

A partir dessa data os familiares de Mariana iniciaram uma busca para encontrá-la. No dia 20 de maio de 1983 o jornal argentino "Clarin" de Buenos Aires publicou um apelo, com a foto da menina, solicitando a quem tivesse qualquer informação de Mariana, que entrasse em contato com as Abuelas da Plaza de Mayo8 ou com o grupo Clamor em São Paulo. Vinte dias após a publicação do apelo, chegou uma carta anônima da Argentina enviada ao grupo Clamor. A carta informava que Miguel Angel Furci, membro do Serviço de Inteligência do Estado (SIDE), estaria com Mariana em um subúrbio de Buenos Aires. A menina havia sido registrada como filha legítima do casal Furci, dois anos após o seu nascimento. Segundo Mariana Zaffaroni,

8 Organização de direitos humanos argentina, fundada em 1977, que tem como finalidade localizar e restituir às suas famílias legítimas todos os filhos sequestrados e desaparecidos durante a última ditadura militar argentina (1976-1983).
Hasta los 17 años creí que me llamaba Daniela Furci. Después de recuperar mi identidad el proceso de adaptación fue bastante lento, yo no me quería hacer cargo de mi historia. Pero cuando nació mi hija, todo empezó a fluir con mi familia. Ahora, al ver personas parecidas a mí, tengo la sensación de pertenecer. Esto yo no lo había sentido nunca a pesar de que tuve una infancia feliz9 10.

Para Samantha Viz Quadrat (2003), a tortura de mulheres, militantes políticas, durante e após a gravidez e, posterior sequestro dos bebês, eram práticas comuns exercidas por membros da ditadura militar argentina. As militantes grávidas eram sequestradas e após a ocorrência dos partos, geralmente em centros clandestinos, os bebês eram retirados das mães com a falsa informação de que seriam entregues aos avós. Após a separação, a mães, geralmente, eram executadas. Esta prática tinha como objetivo difundir o terror entre a população, quebrar o silêncio dos pais, educar as crianças com uma ideologia contrárias à de seus pais biológicos.

Para execução desse plano o exército argentino difundiu instruções de seis manuais específicos. 0 manual intitulado Instrucciones sobre procedimiento a seguir com menores de edadhijos de dirigentes políticos o greminalescuandosus progenitores se encuentrandetenidoso desaparecidos(abril de 1977), ratifica a intenção dos militares de entregar para orfanatos ou famílias de militares crianças com até quatro anos. Acreditava-se que até essa idade, essas crianças estariam livres da influência política de seus pais.

A raíz de um juicio contencioso-administrativo contra el Estado nacional (...), fue localizada enun organismo militar laprueba de que ensu momento existióun do-

\footnotetext{
9 Disponível em: http://plansistematico.blogspot.com. br/2011_11_01_archive.html. Acesso em: 18 de abr. 2017.

10 "Até os meus 17 anos eu achava que meu nome era Daniela Furci. Depois de recuperar minha identidade, o processo de adaptação foi bastante lento, eu não queria me conhecer minha história. Mas quando minha filha nasceu, tudo começou a fluir com minha família. Agora, vendo pessoas parecidas comigo, tenho o sentimento de pertencimento. Isso eu nunca tinha sentido antes, mesmo tendo uma infância feliz"
} 
cumento titulado 'Instrucciones sobre procedimiento a seguir con menores de edadhijos de dirigentes políticos o gremialescuando sus progenitores se encuentrandetenidoso desaparecidos', proveniente delMinisteriodel Interior (abril de 1977). El documento ensí no ha sido hallado, y presumiblementefuedestruido, pero sí se sabe que existió. Esto indica que lasustracción de niños al menos fue representada como probable. Ciertamente, no se sabe cuál era elcontenido de tales instrucciones, pero no parece que haya sido el de instar a lós ejecutoresdirectos a devolver losniños a sus familias de origen. (SANCINETTI; FERRANTE, 1999, p. 169). ${ }^{11}$

Várias das crianças nascidas em cativeiro continuam desaparecidas. Segundo dados da Secretaria Especial de Direitos Humanos (BRASIL, 2009, p. 101), na Argentina, cerca de 500 crianças, filhas de militantes políticos, foram sequestradas durante o período da ditadura militar, sobretudo entre os anos de 1976 e 1983. Dessas crianças, somente $109^{12}$ conseguiram recuperar sua identidade biológica, graças ao trabaIho da Abuelas de La Praza de Mayo ${ }^{13}$. Desde aquela época até a atualidade, as Abuelas mantêm um trabatho de busca de informações sobre as crianças desaparecidas durante o regime militar argentino.

A repressão argentina concentrou-se em Buenos Aires, responsável por quase metade dos desaparecimentos políticos. Contudo, outras cidades como Córdoba, La Plata e Mendoza tiveram intensa atuação das forças armadas nas práticas repressivas. Os principais alvos da repressão eram os sindicalistas, membros do partido peronista, intelectuais, estudantes e jornalistas.

11 "Como resultado de um processo contencioso administrativo contra o Estado nacional (...), foi localizado em um corpo militar a prova de que na época havia um documento intitulado 'Instruções sobre o procedimento a seguir com os filhos de líderes políticos ou quando seus pais são detidos ou desaparecidos ', no Ministério do Interior (abril de 1977). O documento em si não foi encontrado e presumivelmente foi destruído, mas sabe-se que existiu. Isso indica que o rapto de crianças foi pelo menos representado como provável. Certamente, o conteúdo de tais instruções não é conhecido, mas não parece ter sido para incentivar os executores a devolver os filhos às suas famílias de origem".

12 ABUELAS DE LA PLAZA DE MAYO. Testemonios de Netos. Disponível em: https://www.abuelas.org.ar/galeria-videos/testimonios-nietos-10. Acesso em 19 de abr. 2017.

13 Associação civil, criada em 1979, por avós de crianças desaparecidas que iniciaram uma luta pela defesa da vida e pelo direito de manter unidos os membros oriundos do mesmo sangue. Essas avós ficaram conhecidas no mundo inteiro como símbolo da luta contra a ditadura em defesa dos direitos humanos e do direito de voltar a ter o convívio com seus netos e netas.
Diferente do que ocorreu no Brasil e no Chile, advogados que defendiam prisioneiros políticos e juízes também eram alvos da repressão argentina. Segundo Anthony W. Pereira(2010. p. 44), a ditadura argentina expressou uma "quebra radical com a legalidade anteriormente vigente e um ataque em grande medida extrajudicial aos oponentes do regime". A nova "constituição" proibia a atividade dos partidos políticos e cancelava quase todos os direitos civis, sociais e políticos dos cidadãos, em função de um constante Estado de Sítio.

No Paraguai, umas das principais estratégias utilizadas pelas forças repressivas para obtenção de informações consideradas relevantes a respeito das ações praticadas pelos "terroristas" 14 era a prisão e tortura de filhos de presos políticos durante a realização dos interrogatórios.

Um dos testemunhos analisados foi de Maria Felicita Gimenez, prestado à Comision de Verdad y Justicia do Paraguai, no dia 11 de novembro de 2006. Ela foi presa e torturada durante a ditadura militar do general Strossner, junto com sua filha em 1976, quando tinha 24 anos. Em viagem à Assunção por causa da enfermidade de seu sogro, foi detida e presa junto com sua filha Clarisa Carolina Carrillos, que na época tinha três meses. Seu marido Fausto atuava como advogado dos sindicados dos empregados judiciais e foi sequestrado em Formosa no mesmo ano. Segundo Maria Felicita, em entrevista à Comision de Verdad y Justicia, ele não tinha envolvimento com partidos políticos. Ela e sua filha ficaram detidas durante oito meses para investigações.

Além dessas práticas, a tortura psicológica e física era praticada com as crianças, filhas de militantes políticos, como mecanismo de obtenção de informações. 0 depoimento de Marciana Cano, à Comisión de Verdad y Justicia, em 1980 subsidia essa informação:

[] Tenía 11 años, nos subieron llevándonos a todos en el chorro, luego nos llevaron ahí en donde el agua estaba medio estancada y ahí nos sumergieron la ca-

14 Designação dada pelas militantes aos militantes políticos contrários ao governo de Alfredo Stroessner. 
beza y luego sacaban de nuevo así sucesivamente y nos preguntaban otra vez: “¿en dónde está Victoriano Centurión?”, y le volvimos a decir de nuevo que no sabíamos nada y nos volvieron a meter en el agua, ahí casi me ahogué, al no decirle nada me soltaron y le trajo a otra persona, así sucesivamente a cada alumno le traían allí y les torturaban(COMISIÓN..., Tomo III, 2008. p. 91). ${ }^{15}$

A situação dessas crianças estava determinada pelas condições em que se encontravam suas mães. Três situações são identificadas pela Comisión da Verdady Justicia do Paraguai (COMISIÓN...,Tomo V, 2008): muIheres que tinham bebês e foram detidas junto com eles; mulheres que estavam grávidas durante sua detenção e que tiveram seus filhos na prisão; mulheres que tiveram que deixar seus filhos com outros familiares devido à situação de sua prisão.

Há ainda casos como de Maria Margarita Baez de Britez, presa em 17 de agosto de 1976, quando estava grávida de quatro meses. Devido às sucessivas torturas sofridas durante cerca de um mês, teve um aborto e foi submetida a um procedimento cirúrgico para retirada do feto, que teve seu direito de nascer negado pelos agentes da repressão paraguaia. Foi libertada em dezembro de 1976 sem responder a processo e sem receber seu documento de identidade, sendo constantemente ameaçada de morte. Em 16 de fevereiro de 1982 foi novamente sequestrada sem conhecer os motivos da sua apreensão. Foi diariamente torturada durante cerca de oitenta dias.

As consequências das torturas físicas e psicológicas que sofreu são inúmeras: alucinações visuais e auditivas, transtornos motores, fortes dores de cabeça e na coluna vertebral, adormecimento do corpo, taquicardia, problemas de pressão arterial e outros ${ }^{16}$. Durante a ditadura paraguaia, foram detidas 577

15 “... eu tinha 11 anos, eles nos levaram para o córrego, depois nos levaram para onde a água estava meio estagnada e aí submergiram a cabeça e depois saíram novamente e nos perguntaram novamente: "Onde está Victoriano Centurião? ", e nós lhe dissemos novamente que não sabíamos nada e nos colocaram de volta na água, lá eu quase sufoquei, quando eles me libertaram e o trouxeram outra pessoa, então cada estudante foi levado lá e eles foram torturados".

16 ARQUIVOS DO TERROR. Centro de Documentación y Archivo para la Defensa de losDerechos Humanos- CDyA. Corte Suprema de Justiça do Paraguai. Relatório de Maria Margarita Baez de Britez. crianças e adolescentes. Dessas 289 foram torturadas, 39 exiladas, 7 desaparecidas e 3 executadas (COMISIÓN..., Tomo V, 2008, p. 93).

No caso brasileiro, as autoridades militares procuraram manter ações repressivas seletivas, preservando uma "aparente normalidade institucional com focos de ação violenta” (TELES, 2013, p. 8). Contudo, violações dos direitos humanos de crianças e adolescentes, filhas de militantes políticos fizeram parte do cotidiano de muitas famílias brasileiras, ameaçadas pelo medo da tortura e do desaparecimento forçado de seus familiares. 0 caso de Maria Auxiliadora de Almeida Cunha Arantes, sequestrada no dia 13 de dezembro de 1968, junto com seus filhos André ( 3 anos) e a Priscila (2 anos) é exemplo dessa prática. Seus filhos ficaram quatro meses detidos nas dependências militares e submetidos a situações degradantes e subumanas.

\begin{abstract}
A menina tinha pouco mais de dois anos e o menino três, quando toda a família foi seqüestrada em casa, no dia da promulgação do Ato Institucional $n^{0} 5$, em 13 de dezembro de 1968, em Pariconha, no interior do estado de Alagoas. Junto com Maria Auxiliadora, passaram pelo DOPS de Maceió, pela Cadeia Pública, pela Escola de Aprendizes de Marinheiros e pelo Hospital da Polícia Militar, onde ficaram trancados em um quarto destinado aos portadores de doenças infectocontagiosas (BRASIL, 2009, p. 30).
\end{abstract}

Há ainda os casos de crianças que foram presas e, algumas vezes, torturadas junto com seus pais, como é o caso do Carlos Alexandre Azevedo, torturado quando tinha apenas um ano e oito meses de vida no Departamento Estadual de Ordem Política e Social (DEOPS), em 1974. Carlos era filho do jornalista Dermi Azevedo, militante e um dos fundadores do Movimento Nacional dos Direitos Humanos (MDNH). No dia 14 de janeiro de 1974, Carlos Alexandre e sua mãe foram levados à sede do Deops paulista, onde seu pai estava preso. Durante o interrogatório de Dermi, os policiais jogaram Carlos Alexandre no chão e machucaram sua cabeça. A tortura deixou sequelas em Carlos que viveu toda a sua vida submetido a tratamentos com antidepressivos e antipsicóticos. No dia 19 de fevereiro de 2013 Carlos Alexandre pôs fim à sua vida com uma 
overdose de medicamentos ${ }^{17}$.

No dia 30 de setembro de 1969, Virgílio Gomes da Silva Filho foi preso junto com sua mãe Ilda e mais dois irmãos. No dia anterior, seu pai Virgílio havia caído nas mãos dos agentes da repressão e foi assassinado. Sua mãe e irmãos foram presos quando estavam hospedados em uma casa praiana em São Sebastião, São Paulo. Na época, seu irmão mais velho Vlademir tinha oito anos, Virgílio seis anos e Isabel, sua irmã mais nova tinha somente quatro meses. Todos foram detidos na sede da Operação Bandeirantes (OBAN). As três crianças foram arrancadas de sua mãe Ilda e levadas para o Juizado de Menores, onde permaneceram por dois meses. Antes disso passaram por vários interrogatórios.

\begin{abstract}
“A noite era pior. Tinham umas luzes meio roxas lá para os lados do berçário onde estava a Isa. Meu irmão me levava na cozinha para a gente roubar leite e dar de mamar a ela", recorda. O furto tinha um propósito: Isabel teve uma grave desidratação enquanto estava no Juizado. 0 instinto protetor impeliu os dois a dormir embaixo do berço do bebê, para impedir que fosse adotada. A adoção, aliás, pairava no ar. "Eles nos levavam para ver umas casas bonitas e perguntavam se gostaríamos de morar ali”, conta Virgílio. Nessas ocasiões, o menino permanecia mudo, protegido por uma teimosa indiferença (BRASIL, 2009, p. 64).
\end{abstract}

Ilda ficou presa até o ano de 1979, permanecendo incomunicável a maior parte do tempo. As crianças foram separadas e cada uma delas foi morar com um tio. Às vezes elas se reuniam e ficavam paradas em frente a um poste onde sua mãe, ainda presa, poderia avistá-los. Após ser libertada e reunir sua família, Ilda e seus filhos foram morar em Cuba onde permaneceram até concluírem o curso universitário (PIMENTA; TEIXEIRA, 2009).

Em junho de 1970 quatro crianças - Ernesto (2 anos e 3 meses), Zuleide ( 4 anos e 10 meses), Luiz Carlos (6 anos e 7 meses) e Samuel (9 anos),presas com a avó e os pais, foram enquadrados como subversivos e banidos do País por decreto do então presi-

17 BECKER, Marcelo Miranda. Morre em São Paulo homem torturado pela ditadura quando tinha um ano. Terra. $18 \mathrm{fev}$. 2013. Disponível em: <http://noticias.terra.com.br/brasil/,ead367d062fec310VgnVCM3000009acceb0aRCRD.html>. Acesso em 01 mar. 2017. dente Emílio Garrastazu Médici. Elas foram embarcadas em um voo rumo a Argel, capital da Argélia. Após presenciarem a tortura de seus pais e avó e de serem torturadas, foram banidas do Brasil com base no Ato Institucional $n^{0} 13$ que permitia "banir do território nacional o brasileiro que, comprovadamente, se tornar inconveniente, nocivo ou perigoso à segurança nacional" (VILLAMÉA, 2013, p. 55).

Segundo Carlos Fico (2001) essas técnicas e outras similares foram utilizadas pelo governo brasileiro e exportadas para o Chile e o Uruguai nos anos de 1970, conforme pode ser verificado no documento a seguir.

\begin{abstract}
Para todos os brasileiros que tiveram oportunidade de manter contato com os oficiais de informações do exército argentino, chileno e uruguaio, é reconfortante ouvir o testemunho desses oficiais que, ao estudarem o nosso SISSEGIN, sentem que estamos certos e ficam admirados de ser ele uma criação inteiramente nossa. 0 Chile e o Uruguai adotaram em seus países um sistema semelhante ao nosso, adaptados às leis e às peculiaridades existentes em cada um deles. 0 s resultados da contra-versão e do contra-terrorismo são evidentes nesses dois países. A Argentina continua a combater a subversão e o terrorismo através de suas forças policiais e não tem tido os êxitos esperados em que pese todas as medidas sócio-econômicas, aliadas a outras de caráter liberal que aquela nação irmã vem adotado18 (FICO, 2001, p. 135).
\end{abstract}

Outra técnica empregada nos interrogatórios era a prática de desumanização e coisificação do preso político. Após ingressarem nos centros clandestinos de tortura e detenção os presos eram destituídos de toda a dignidade humana. Na Argentina, cada preso recebia um número que o identificava. Assim como um objeto identificado pelo seu código de barra, o preso era identificado pelo seu número. 0 processo de coisificação do preso tinha a intenção de desumanizar o prisioneiro, rompendo com todos os seus laços elementares de convivência e de direitos civis.Segundo Calveiro (2013, p. 51), a linguagem utilizada pelos militares argentinos ao se referirem as práticas realizadas nos campos clandestinos de detenção e tortura é elucidativa da desu-

18 Sistema de Segurança Interna. SISSEGIN. Documento classificado como "secreto". [1974?]. Capítulo 2, fls. 44-45. 
manização dos presos políticos.

“Não se mata, 'empacota-se'. Não se seqüestra, 'suga-se'. [...] Não há massacres coletivos e sim 'transferências', 'carrinhos', ventiladores”'. Não há referência ao aspecto humano dos presos, eles são tratados como mercadorias que são transportadas e eliminadas ao bel prazer dos militares das forças repressoras. Nem mesmo a decisão sobre a vida e a morte do preso lhe pertencia, mas estava a cargo da vontade dos interrogadores. Se por um lado a substituição dos termos e palavras empregadas para se referir aos presos e as práticas realizadas são significativas do processo de desumanização dos prisioneiros, por outro elas "inocentam" as ações hediondas cometidas pelos agentes da repressão e alivia a responsabilidade dos militares.

As falas do general Ramón Campos, chefe de polícia de Buenos Aires em 1976, durante uma entrevista, elucida sua isenção com relação à responsabilidade pela morte de crianças durante o regime militar argentino: "Não eliminei nenhuma criança pessoalmente"(CALVEIRO, 2013, p. 50).

Nenhuma das crianças que tiveram os pais assassinados, clandestinos ou encarcerados teve o direito de desfrutar da convivência familiar, escolar ou comunitária. Seus relacionamentos eram marcados por restrições e segredos. Os finais de semana eram passados em cadeias, únicas ocasiões que podiam visitar seus pais.

\section{RECORDAR PARA VIVER: A IMPORTÂNCIA DO RESGATE DO PASSADO}

Os crimes cometidos pelos agentes públicos ou privados do Estado brasileiro que promoveram práticas de tortura, desaparecimento forçado e ocultação de cadáveres configuram-se como crimes de lesa-humanidade de acordo com a Convenção sobre a Imprescritibilidade dos Crimes de Guerra e dos Crimes Contra a Humanidade, de 26 de novembro de 1968, com jurisprudência da Corte Interamericana de Direitos
Humanos, sendo portanto imprescritíveis ${ }^{19}$. 0 Brasil foi um dos países que assinou a Convenção Americana sobre a Imprescritibilidade dos Crimes Guerra e dos Crimes contra a Humanidade e depositou sua ratificação em 25 de setembro de 1992 (BICUDO, 2009; DANTAS, 2009; PAOLINELLI; MAGRANI, S/D).

No entanto, o Supremo Tribunal Federal (STF), rejeitou, no dia 29 de abril de 2010, por sete votos a dois, o pedido de revisão da Lei de Anistia proposto pela Ordem dos Advogados do Brasil, que questionava a concessão de anistia aos agentes de Estado envolvidos em crime como tortura, assassinatos e desaparecimentos durante o regime militar. No entender dos membros do STF, a anistia foi responsável por uma transição pacífica entre o regime autoritário militar e o regime democrático atual.

Ou seja, considerando a validade da Lei da Anistia brasileira, no Estado de Direito atual, não existem, judicialmente, instrumentos aptos para a punição de crimes de lesa humanidade cometidos durante o período da ditadura militar brasileira. Essa lei que propõe uma reintegração de direitos políticos sem propor uma ação pública de reparação aos atingidos pelas violações dos direitos humanos, sobretudo às crianças que tiveram suas infâncias violadas, acaba por silenciar os testemunhos das vítimas e familiares de desaparecidos políticos no Brasil.

$\mathrm{Na}$ Argentina, os crimes das ditaduras foram exibidos por meio de inúmeros testemunhos que ganharam espaço e voz nos julgamentos dos responsáveis pelas violações dos direitos humanos dos cidadãos contrários à ditadura. Segundo Beatriz Sarlo (2007, p. 38), no âmbito judicial, o relato das experiências vividas pelas vítimas representou uma "cura" para o processo de coisificação por que passaram durante o período em que estiveram nos campos de concentração e da alienação de setores da sociedade civil, que, emudecida pelo medo ou pela propaganda autoritá-

19 Convenção sobre a Imprescritibilidade dos crimes de Guerra e dos Crimes Contra a Humanidade, de 26 de novembro de 1968. Disponível em: http://www.direitoshumanos.usp.br/index.php/Sistema-Global.-Declara\%C3\%A7\%C3\%B5es-e-Tratados-Internacionais-de-Prote\%C3\%A7\%C3\%A3o/convencao-sobre-a-imprescritibilidade-dos-crimes-de-guerra -e-dos-crimes-contra-a-humanidade.html. Acesso em 14 jul. 2017. 
ria, se omitiu e se recusou a denunciar as atrocidades cometidas pelo governo militar.

Os testemunhos das vítimas e familiares nunca representarão a experiência vivida naquele período, contudo é a partir de verdades subjetivas relatadas via memórias resgatadas que os sujeitos se tornam conhecíveis, que as atrocidades se tornam públicas e que as memórias, antes censuradas, ganham espaço na história política e social de uma nação.

Enquanto na Argentina os relatos públicos das vítimas e familiares ganharam espaço e notoriedade na reconstrução histórica do período do regime militar argentino, transformando-se em instrumentos de indignação e impulso para a transição democrática sob o signo do Nunca mais, no Brasil o descaso com os testemunhos de familiares de mortos e desaparecidos políticos, bem como dos presos e exilados políticos, promoveram uma "transição lenta, gradual e segura"20, garantindo a impunidade de crimes de lesa humanidade praticados durante a ditadura militar brasileira.

Nossa experiência histórica nos mostra que é possível, apenas de forma figurativa, omitir o passado, evitar discuti-lo e investigá-lo. Todavia, a lembrança deste tempo é como um cheiro que nos acomete quando menos esperamos e que insiste em se fazer presente, pois, segundo Beatriz Sarlo (2007, p. 10), o presente é o único tempo apropriado para lembrar. A lembrança não se afirma pelo passado, mas sim pelos seus direitos: direito a justiça, a vida e a subjetividade de quem se recorda. Nesse sentido, o passado guarda um conflito entre a memória e a história, pois “nem sempre a história consegue acreditar na memória, e a memória desconfia de uma reconstituição que não coloque em seu centro os direitos da lembrança” (SARLO, 2007, p. 9).

20 A estratégia usada pelo presidente Ernesto Geisel para acalmar os crescentes ânimos descontentes da sociedade civil foi a política de distensão que previa um retorno lento, gradual e seguro à ordem democrática plena. 0 objetivo desta política era conter a pressão social e política da sociedade civil. A premissa básica do Governo era: "Continuidade sem imobilismo", que impunha, simultaneamente, mecanismos de repressão e de controle social e de liberalização. A política de distensão de Geisel se estruturava no controle do aparato repressivo e na descompressão do regime, através de medidas de liberalização política. Pretendia-se efetuar um processo de desmonte dos órgãos repressivos e de informação, sem alterar profundamente o equilíbrio de forças e a ordem política.
Um Estado ou um governo pode proibir o retorno ao passado, mas não pode nunca o eliminar, pois implicaria na eliminação de todos aqueles que se recordam dele. Ao tentar omitir o passado, seja por meio da alienação ideológica, seja pelo desaparecimento forçado de milhares dos sujeitos históricos, as lembranças daqueles que o viveram insistem em se fazerem percebidas a partir das ações voluntárias e involuntárias das lacunas do tempo presente.

A Comissão Nacional da Verdade do Brasil, criada pela Lei 12528/2011 e instituída em 16 de maio de 2012, que teve por finalidade apurar casos de graves violações de direitos humanos ocorridos entre $18 \mathrm{de}$ setembro de 1946 e 5 de outubro de 1988, reflete essa impossibilidade objetiva de omitir o passado, de evitar falar dele e de ignorá-lo. Sua implantação veio a revigorar o desejo voluntário e involuntário de familiares de mortos, desaparecidos e torturados políticos, durante a ditadura militar brasileira, de lembrança, de justiça e de plenitude democrática. Evitar conhecer e discutir este passado é deixar de perceber os valores que orientavam a sociedade civil e o Estado sobre o qual o regime se sustentava. É apagar lembranças, sentimentos, ações e inações que ainda se fazem presentes e que inviabilizam a conquista da nossa cidadania plena.

No dia 25 de março de 2014, o coronel reformado do Exército brasileiro, Paulo Malhães, admitiu que torturou, matou e ocultou cadáveres de militantes políticos durante a ditadura militar brasileira na chamada "Casa da Morte", em Petrópolis, em depoimento concedido à Comissão Nacional da Verdade. Em seu relato, Malhães não demonstrou arrependimento ou remorso com relação à morte, tortura ou ocultação de cadáveres realizados. Para o coronel a tortura era necessária para a obtenção de informações e deveria ser aplicada aos presos comuns (FRANCO, 2014). A respeito da ocultação de cadáveres, segundo Malhães, foi um recurso utilizado com a intenção de não se deixar provas das práticas cometidas com os presos políticos.

Nas palavras do coronel: "Naquela época não existia DNA. Quando você vai se desfazer de um corpo, 
quais partes podem determinar quem é a pessoa? Arcada dentária e digitais. Quebrava os dentes. As mãos, cortava, daqui para cima” (FRANCO, 2014,on-line). Ao se referir às vítimas da repressão política do regime militar, Malhães as tratou como "terroristas" e demonstrou não sentir remorso pelo o que fez, "quando vejo uma pessoa reclamar que um ente querido morreu, pergunto: se tivesse ficado ao lado da esposa e dos filhos isso teria acontecido?" (FRANCO, 2014, on-line).

Segundo Ribeiro Neto e Féres-Carneiro (2012, p.66-67), “com a negação da abertura dos arquivos militares e a impossibilidade de julgamento dos atos de tortura e desaparecimento, impede-se a reparação, produzindo uma memória oca com a impossibilidade de uma memória psíquica na história da família”.

No Brasil, durante quase cinquenta anos ${ }^{21}$ uma parcela significativa da sociedade não pode assumir e contar suas próprias histórias. Para entender o passado ditatorial brasileiro torna-se necessário dar ouvidos aos discursos silenciados pela opressão e pela alienação, pela omissão proposital de determinados conteúdos nos livros didáticos, pelo desconhecimento dos fatos ocorridos nos centros clandestinos de detenção e tortura de militantes políticos.

0 entendimento desse período requer o resgate de lembranças, embora traumáticas e recentes, são cruciais para o desenvolvimento da cidadania e da democracia brasileira. A sociedade civil necessita de relembrar fatos, de reinterpretar passados, de refletir situações vividas para finalmente afirmar: 19641985, entender para não repetir, para não esquecer, para prosseguir.

\section{CONSIDERACÕ̃ES FINAIS}

Esta pesquisa procurou relatar alguns casos de violações dos direitos humanos no Cone Sul de três

21 Consideramos esta temporalidade relativa aos vinte e um anos de ditadura militar brasileira acrescido dos vinte e sete anos do período que se estende do término da ditadura até o ano da criação da Comissão Nacional da Verdade, período em que as memórias e relatos dessa história foram sistematicamente censurados, ora pelas forças governamentais repressivas, ora pela alienação da sociedade civil, ensurdecida pelo discurso dominante da existência de uma democracia plena no Brasil. gerações (avós, pais e filhos) de pessoas que, devido às convicções políticas contrárias à ideologia oficial, foram usurpadas de seus direitos humanos e de cidadãos. Acreditamos que a reconstituição da memória deste período (1954-1990), por meio da análise dos documentos do Fundo Clamor e dos "Arquivos do Terror”, contribui para a recuperação de uma história emudecida pelos discursosautoritários dos órgãos da repressão política e militar. 0 resgate destes fatos por de testemunhos e registros documentais possibilitou a recuperação de histórias sobre violações de direitos humanos de cidadãos que vislumbravam um futuro mais democrático para seus países.

Relatar essas histórias é contar casos de lutas em defesa dos direitos humanos, também de casos de usurpação desses direitos, com a utilização clandestina, mas explícita, de métodos de barbárie, de violência física, psicológica e cultural, capaz de gerar uma cultura do medo alimentada pelo terrorismo de Estado vigente nesses países. Abordar a memória desses fatos, embora subjetivos e, aparentemente, similares, traz à tona a recuperação dos modos de ação e repressão das forças armadas que governavam os países do Cone Sul durante o período de 1954 a 1990. Retratar esses fatos é revelar as dificuldades enfrentadas pelos parentes e amigos dos desaparecidos políticos e de seus filhos e filhas, sequestrados e torturados durante os regimes militares.

As memórias pessoais e os testemunhos registrados nos arquivos pesquisados narram fatos históricos presentes ou não na memória coletiva desses países. Nesse sentido, o resgate das memórias pessoais, mesmo que subjetivas, são cruciais para percebermos a política de cooperação adotada entre os países do Cone Sul, bem como o protagonismo brasileiro nas ações de repressão, troca de prisioneiros e treinamento em áreas de inteligência e técnicas de interrogatórios.

Acreditamos que o conhecimento desses fatos possibilita às gerações presentes e futuras a chance de conhecer seu passado, seus dirigentes, suas forças armadas e suas formas de ação. Recordar esses fatos é oferecer às sociedades do Cone Sul a chance de co- 
nhecer seu passado, aprender com ele e, a partir disso, desenhar o seu futuro. Afinal, segundo a psicóloga Eclea Bosi (1979, p. 362) "um dos mais cruéis exercícios da opressão é a espoliação das lembranças”.

\section{REFERÊNCIAS}

ABUELAS DE LA PLAZA DE MAYO. Testemonios de Netos. Disponível em: <https://www.abuelas.org.ar/ galeria-videos/testimonios-nietos-10>.

Acesso em: 19 abr. 2017.

ARDITTI, R.; LYKES, M. B. Abuelas de laplaza de mayo. Restituición de niños. Buenos Aires: Editorial Universitaria de Buenos Aires, 1997.

BECKER, Marcelo Miranda. Morre em São Paulo homem torturado pela ditadura quando tinha um ano. Terra. 18 fev. 2013. Disponível em: <http://noticias. terra.com.br/brasil/,ead367d062fec310VgnVCM30000 09acceb0aRCRD.html>. Acesso em: 1 mar. 2017.

BICUDO, Hélio. Anistia e Crimes contra a humanidade que não prescrevem. Com Ciência. Revista Eletrônica de Jornalismo Científico. 10 mar. 2009. Disponível em: <http://www.comciencia.br/ comciencia/handler.php?section=8\&edicao=43\& id=525>. Acesso em: 14 jul. 2017;

BOSI, Ecléa. Memória e sociedade: Lembranças de Velhos. São Paulo: TA Queiroz, 1979. p.362.

BRASIL. Presidência da República. Secretaria Especial dos Direitos Humanos. Direito à memória e à verdade: histórias de meninas e meninos marcados pela ditadura / Secretaria Especial dos Direitos Humanos. Brasília: Secretaria Especial dos Direitos Humanos, 2009.

CALVEIRO, Pilar. Poder e desaparecimento: os campos de concentração na Argentina. Trad. Fernando Correa Prado. São Paulo: Boitempo, 2013.
COMISIÓN DE VERDAD Y JUSTICIA. Informe

Final: LaSecuelas de lãs Violaciones de Derechos Humanos, La Experiencia de lasVíctimas. Tomo III. Asunción: CVJ, 2008. p.93.

\section{COMISIÓN DE VERDAD Y JUSTICIA. Informe}

Final: LaSecuelas de lãs Violaciones de Derechos Humanos, La Experiencia de lasVíctimas. Tomo V. Asunción: CVJ, 2008. p.93.

DANTAS, Wellson Rosário Santos. A imprescritibiliade dos crimes políticos e a não recepção da Lei de Anistia pela Constituição da República de 1988. JurisWay. 22 dez. 2009. Disponível em: <http://www.jurisway.org.br/v2/ dhall.asp?id_dh=3360>. Acesso em: 14 jul. 2017

FERNANDES, Ananda Simões. "Esta guerra nos es contra losniños": o sequestro de crianças durante as ditaduras de Segurança Nacional no Cone Sul. In: PADRÓS, Enrique Serra; NUNES, Cármen Lúcia da Silveira; LOPES, Vanessa Albertinence; FERNANDES, Ananda Simões (Org.). Memória, verdade e justiça: as marcas das ditaduras do Cone Sul. Porto Alegre: ALRS, 2011.

FICO, Carlos. Como eles agiam: os subterrâneos da Ditadura Militar: espionagem e polícia política. Rio de Janeiro: Record, 2001.

FRANCO, Bernardo Mello. Coronel admiti que torturou, matou e ocultou corpos na ditadura militar. Folha de São Paulo. 25 mar. 2014. Disponível em: <http://www1.folha.uol.com.br/ poder/2014/03/1430795-coronel-admite-quetorturou-matou-e-ocultou-corpos-na-ditaduramilitar.shtml>. Acesso em: 25 jun. 2017.

HABERMAS, Jurgen. Teoría de

laaccióncomunicativa: Crítica de larazón

Funcionalista. 4.ed. Madrid: Tauros, 1999. Tomo II.

JOSÉ, Emiliano. A hora azul. Carta capital. São 
Paulo. Sociedade. 27 out. 2008. s/p. Disponível em: <http://www.cartacapital.com.br/sociedade/a-horaazul>. Acesso em: 20 maio 2017.

LIMA, Samarone. Clamor: a vitória de uma conspiração brasileira. Rio de Janeiro: Objetiva, 2003.

PAOLINELLI, Camilla Mattos; MAGRANI, Eduardo Jose Guedes. O Modelo transacional brasileiro e a imprescritibilidade dos crimes de tortura como dever jurídico de memória: pela conformação do princípio de Direito Internacional ao paradigma da Constitucionalidade democrática. In: LEAL, Rogério Costa; EIBAUM, Lúcia; MEYER-PFLUG, Samantha Ribeiro (Coord.).Justiça de Transição: memória, verdade e justiça. Rio de Janeiro: FUNJAB, S/D. Disponível em: <http://www.publicadireito.com.br/ar tigos/?cod=d814f4e3dcf9e6f4>.

Acesso em: 14 jul. 2017

PEREIRA, Anthony W. Ditadura e repressão: 0 autoritarismo e o Estado de Direito no Brasil, no Chile e na Argentina. São Paulo: Paz e Terra, 2010.

PIMENTA, Edileuza; TEIXEIRA, Edson. Virgílio Gomes da Silva: de retirante a guerrilheiro. São Paulo: Plena Editorial, 2009.

PIRES, Carol. STF rejeitou a revisão da Lei da Anistia por 7 a 2. Estadão. São Paulo. Política. 29 abr. 2010. s/p. Disponível em: <http://politica.estadao.com.br/ noticias/geral,stf-rejeitou-revisao-da-lei-de-anistiapor-7-votos-a-2,544833>. Acesso em: 20 maio 2017.
QUADRAT, Sandra Viz. 0 direito à identidade: a restituição de crianças apropriadas nos porões das ditaduras militares do Cone Sul. História (on-line), v.22. n.2. p.167-181, 2003.

RIBEIRO NETO, Míria; FÉRES-CARNEIRO, Terezinha.

Silêncio e Luto Impossível em Famílias de Desaparecidos Políticos Brasileiros. Psicologia e Sociedade,n.24,p.66-74, 2012.

SANCINETTI, Marcelo A;FERRANTE, Marcelo. El derecho penal enlaprotección de losderechos Humanos. Buenos Aires: Hammurabi, 1999.

SARLO, Beatriz. Tempo passado: cultura da memória e guinada subjetiva. Trad. Rosa Freire d' Aguiar. São Paulo: Companhia das Letras; Belo Horizonte: UFMG, 2007.

TELES, Janaína de Almeida. Ditadura e Repressão no Brasil e na Argentina: paralelos e distinções. In: CALVEIRO, Pilar. Poder e desaparecimento: os campos de concentração na Argentina. São Paulo: Boitempo, 2013.

VILLAMÉA, Luíza. Quando meninos são fichados como terroristas. Brasileiros, São Paulo, n.68, p. 5464, mar. 2013. 
